\title{
Traditional knowledge of biodiversity in the community surrounding Giam Siak Kecil-Bukit Batu Biosphere Reserve, Riau, Indonesia
}

\author{
HERMAN SUPARMAN SIMANJUNTAK ${ }^{1}$, ENDANG SUKARA ${ }^{2}$, DOLLY PRIATNA ${ }^{3}$
}

'Biology Graduate Program, Department of Biology, Universitas Nasional, Jl. R.M. Harsono, Ragunan, Jakarta 12550, Indonesia.

${ }^{2}$ Center Environmental Ethic Studies, Universitas Nasional, Jl. Sawo Manila No.61, Pejaten Barat, Jakarta 12520, Indonesia. ${ }^{3}$ Graduate School of Environmental Management, Pakuan University, Jl. Pakuan PO Box 452, Bogor 16143, Indonesia

Corresponding author: herman.ssimanjuntak@gmail.com

Submitted 7 October 2021; Accepted 16 October 2021

\begin{abstract}
The Objective of this study is to analyze the potential for biodiversity and traditional knowledge in the buffer zone of the Giam Siak Kecil-Bukit Batu Biosphere Reserve (GSK-BB). The research was conducted descriptively-quantitatively by analyzing two variables, i.e. biodiversity and community traditional knowledge. Biodiversity monitoring report documents from PT Sakato Pratama (PT SPM) and PT Bukit Batu Hutan Alam (PT BBHA), profiles of Temiang and Sepahat villages, questionnaire data taken from village community representatives, as well as the results of in-depth interviews were used in the analysis. The results show that in the PT SPM area, there are 177 species of plants and 55 species of animals. Meanwhile in the PT BBHA area there are 146 species of plants and 46 species of animals. Based on information from the community of Temiang Village, there are 51 species of plants and 18 species of animals, while according to the people of Sepahat Village, there are 73 species of plants and 83 species of animals. The biodiversity utilized by the community in the two villages consists of 36 species of plants and 15 species of animals, but only three species are wild animals, i.e. sun bear (Helarctos malayanus), horseshoecrab (Limulus sp.), and seahorse (Hippocampus sp.), and one species of plant (rattan, Calamus sp.). The rest are cultivated plants and livestock. From the analysis, it can be concluded that the relationship between biodiversity and traditional knowledge in both Temiang and Sepahat Villages is very limited. Awareness of the strategic value of wild plants and wildlife in the buffer zone of the biosphere reserve needs to be increased.
\end{abstract}

\begin{abstract}
ABSTRAK
Penelitian ini bertujuan untuk menganalisis potensi keanekaragaman hayati dan pengetahuan tradisional di zona penyangga Cagar Biosfer Giam Siak Kecil-Bukit Batu (GSK-BB). Penelitian dilakukan secara deskriptif-kuantitatif dengan menganalisis dua variable, yaitu keanekaragaman hayati dan pengetahuan tradisional masyarakat. Dokumen laporan monitoring keanekaragaman hayati dari PT Sakato Pratama (PT SPM) dan PT Bukit Batu Hutan Alam (PT BBHA), profil Desa Temiang dan Sepahat, data kuisioner yang diambil dari perwakilan masyarakat desa, serta hasil wawancara mendalam digunakan dalam analisis. Hasil menunjukan bahwa di kawasan PT SPM tercatat terdapat 177 jenis tumbuhan dan 55 jenis satwa. Sementara itu di kawasan PT BBHA terdapat 146 jenis tumbuhan dan 46 jenis satwa. Berdasarkan informasi dari masyarakat Desa Temiang terdapat 51 jenis tumbuhan dan 18 jenis satwa, sedangkan menurut masyarakat Desa Sepahat terdapat 73 jenis tumbuhan dan 83 jenis satwa. Keanekaragaman hayati yang dimanfaatkan oleh masyarakat di kedua desa tersebut terdiri atas 36 jenis tumbuhan dan 15 jenis satwa, namun hanya tiga jenis yang merupakan hewan liar, yaitu beruang madu (Helarctos malayanus), belangkas (Limulus sp.), dan kuda laut (Hippocampus sp.), serta satu jenis tumbuhan (rotan, Calamus sp.). Selebihnya merupakan tanaman budidaya dan hewan ternak. Dari hasil analisis, dapat ditarik kesimpulan sementara bahwa hubungan keanekaragaman hayati dengan pengetahuan tradisional di kedua desa Temiang dan Sepahat sangat terbatas. Kesadaran tentang nilai strategis tumbuhan dan satwa liar yang ada di kawasan penyangga cagar biosfer perlu ditingkatkan.
\end{abstract}

Keywords: biodiversity, biosphere reserve, buffer zone of Giam Siak Kecil-Bukit Batu, traditional knowledge

\section{INTRODUGTION}

UNESCO has denominated the Giam Siak-Kecil Bukit Batu Biosphere Reserve, located in Bengkalis District and Siak District Riau province as the 7th biosphere reserve in Indonesia by 2009. The main purpose of the development of GSK-BB Biosphere Reserve is to support the achievement of sustainable development of landscape, peat swamp forest, lakes and their water system that had been converted into industrial forest, plantation and settlement (Qomar,
2017) Looking at the local community activities who lives around area of GSK-BB Biosphere Reserve, many villagers are still utilizing biodiversity to meet their daily needs through traditional methods such as harvesting forest honey by climbing sialang tree, fishing using bubu or lukah, and various types of biodiversity processed medicines based on community traditional knowledge (Anna, 2013). Utilizing biodiversity, landscape and local culture in tourism is believed to be able to conserve the natural and cultural environment and be able to prosper the community around the region (Yosevita, 2013). The 
buffer zone area of the GSK-BB Biosphere Reserve is the focus of this research, involving respondents from Temiang and Sepahat villages located in the buffer zone area. The buffer zone area serves as a protector to the core zone (Cecep, 2018). The selection of this zone due to its opportunity to be further expanded to support biodiversity conservation in the area that will potentially preserve the core zone. Based on the description, this research was conducted to identify the biodiversity and traditional knowledge manageable in the buffer zone area of GSK-BB Biosphere Reserve in Riau.

\section{METHODS}

\section{Location}

The research was conducted in February-April 2020, in buffer zone area of GSK-BB Biosphere Reserve (Figure 1) which covers the protected area of PT Sakato Pratama Makmur (PT SPM) and PT Bukit Batu Hutan Alam (PT BBHA), as well as two villages in Bandar Laksamana Subdistrict which are both paced in the buffer zone area of GSK-BB Biosphere Reserve. Those two villages are Temiang and Sepahat.

Temiang Village was chosen for several reasons as follow: (a) part of the village area is in the buffer zone of GSK-BB Biosphere Reserve, (b) Its villagers carry out many activities in the buffer zone and core zone area of GSK-BB Biosphere Reserve (rubber plantation, oil palm plantation, agricultural field, and river fishing). Sepahat Village was chosen because: (a) part of the village area is included in the buffer zone of the GSK-BB Biosphere Reserve, (b) The Sepahat village government is developing coastal tourism, (c) the lack of interaction of Sepahat village communities to the core zone of the GSK-BB Biosphere Reserve. Tools used in data collection phase are stationery, recorder, camera, laptop, questionnaires, and data storage devices.

The research method using descriptive-quantitative method. The aspects studied in this research are:

1. Identify biodiversity potential in GSK-BB buffer zone with document studies, questionnaires and in-depth interviews.

2. Identify traditional knowledge of the community with questionnaires and in-depth interviews

The data and information obtained will be analyzed using quality of diversity of flora and fauna species according to Fandeli (2000). Questionnaire results are processed to find out the level of public knowledge on biodiversity. In-depth interviews conducted with community leaders to enrich information about knowledge of biodiversity utilization by the community.

In obtaining an assessment or scoring, the main component of the assessment is calculated by using the formula: $\mathrm{S}=\mathrm{N}$ x B

Description:

$\mathrm{S}=$ Score/value

$\mathrm{N}=$ Number of values of elements on the criteria

$\mathrm{B}=$ Value weight

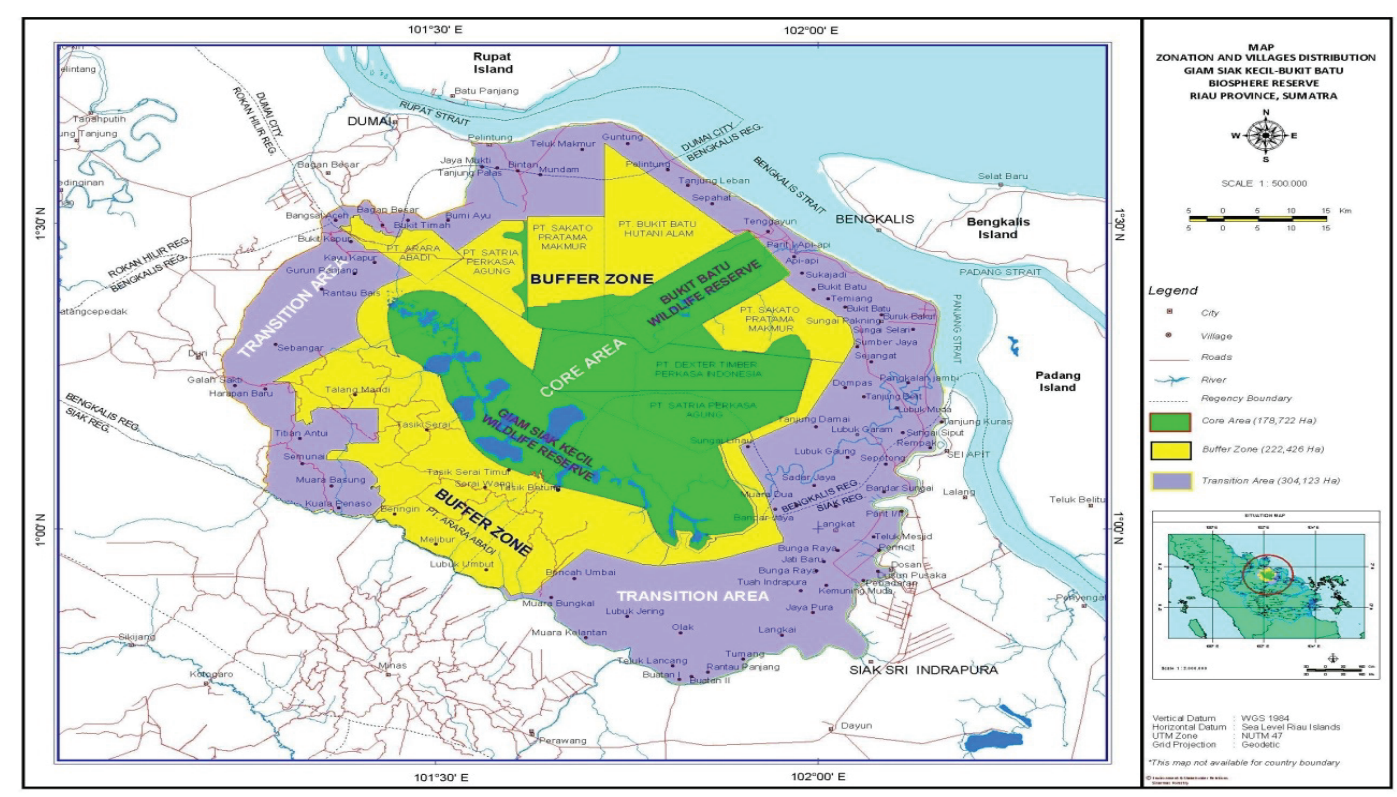

Figure 1. The map of research site map (red boxes in two companies and round red in two villages) 


\section{Location}

\section{Biodiversity analysis in GSKBB buffer zone}

The analysis was conducted by collecting data on the company's biodiversity report in 2018 (PT SPM and PT BBHA) and questionnaires and in-depth interviews with the community. The company's biodiversity report data is then processed using assessment guidelines from Fandeli (2000) to obtain information on the quality of flora and fauna diversity in the GSK-BB buffer zone area. The quality of diversity referred to by Fandeli (2000) is related to the diversity of flora and fauna. The high diversity of flora and fauna means that the area has a high tourism potential. Fandeli (2000) makes the diversity quality criteria presented in the Table 1 and Table 2.

Table 1. Criteria for the quality of plant diversity

\begin{tabular}{cll}
\hline Scale & \multicolumn{1}{c}{ Number of species } & Category \\
\hline 1 & There are $\leq 5$ species of plant & Bad \\
\hline 2 & There are $6-10$ species of plant & Poor \\
\hline 3 & There are $11-20$ species of plant & Fair \\
\hline 4 & There are $21-31$ species of plant & Good \\
\hline 5 & There are $\geq 31$ species of plant & Very Good \\
\hline
\end{tabular}

Table 2. Criteria for the quality of animal diversity

\begin{tabular}{cll}
\hline \multirow{2}{*}{ Scale } & \multicolumn{1}{c}{ Number of species } & Category \\
\hline 1 & There are $1-2$ species of animal & Bad \\
\hline 2 & There are $3-5$ species of animal & Poor \\
\hline 3 & There are $6-10$ species of animal & Fair \\
\hline 4 & There are $11-15$ species of animal & Good \\
\hline 5 & There are ${ }^{>} 15$ species of animal & Very Good \\
\hline
\end{tabular}

Questionnaires are used to explore people's knowledge about biodiversity in the GSK-BB buffer zone. Questionnaire results are processed to determine the level of public knowledge about biodiversity. In-depth interviews with community leaders to enrich information about people's knowledge of biodiversity.

\section{Traditional knowledge analysis}

The analysis was conducted by collecting data through questionnaires and in-depth interviews to obtain information on people's knowledge in the utilization of biodiversity (in the form of traditional medicine, cultural works, customary rituals, and artworks) in the region. Questionnaire results are processed to determine the level of knowledge of the community in utilizing biodiversity. In-depth interviews with several community leaders to enrich information about people's knowledge about biodiversity utilization.

\section{RESULTS AND DISGUSSION}

The buffer zone areas in this study were areas in-and-around the PT SPM and PT. BBHA concession area, Sepahat village and Temiang village, Bandar Laksamana Subdistrict. The quality of biodiversity in the buffer zone refers to Fandeli (2000) assessment criteria with following results: (a) Area of PT SPM species diversity quality of flora and fauna is very high, with more than 31 species of plants and more than 15 species of animals found (177 species of plants, which are 13 protected status; 55 species of animals, which are 33 protected status); (b) Area of PT BBHA the of species diversity quality of flora and fauna is very high, with more than 31 species of plants and more than 15 species of animals found (146 species of plants, which are 18 protected status; 46 species of animals, which are 21 protected status); (c) In Temiang village the quality of flora and fauna diversity is very high with more than 31 species of plants and more than 15 species of animals found (51 species of plants, 18 species of animals) (d) In the villages of Temiang and Sepahat the quality of flora and fauna diversity is very high with more than 31 species of plants and more than 15 species of animals (73 species of plants, 83 species of animals).

Traditional knowledge of Temiang and Sepahat village communities revolves around the utilization of several species of flora and fauna for the medicine, traditional rituals, handicrafts, and arts. The most widely used species of plants as a medicine mostly cultivated independently or grows naturally in the dwelling / yard and the majority are from the family of Zingiberaceae. Based on the way it is processed, 55\% made by general community, not specifically made by village shamans. Supported by the respondent's statement that knowledge of plants and medicinal plants is obtained pass from parents to their generations through observation and practice. The most widely processed and used part of the plant as a medicine is the leaf. The utilization of medicinal plants by the villagers of Temiang is usually to overcome diseases such as: stomach pain or ulcers, colds, to increase stamina and endurance, to increase appetite, fever, cough, abdominal pain, diabetes, cholesterol and gout, and minor injuries.

Animals that are often used as medicine include squirrels, earthworms and aruan/gabus or snakehead fish. Squirrel (Scandentia sp.) is the most widely used animal as a medicine to overcome diabetes. The practice of using squirrels that are widely found in the gardens since many diabetics feel positive changes after consuming squirrel meat. The second most used animal as a medicine is earthworms (Lumbricina sp.) used for the treatment of asthma which are commonly found in the yard soil. The third most used animal as a medicine is snakehead fish that are found in river or trench areas (Channa stiriata) that are efficacious to treat deep wounds or postoperative wounds (Budi, 2016). Based on data 
obtained in Temiang Village, it is known that the most widely used animal parts as medicine are the meat $(40 \%)$ and the whole body part $(30 \%)$. Temiang villagers use animals for the treatment of diabetes, shortness of breath, postoperative wounds, weak stamina, fractures and sprains, toothache and ulcers. There is also one species of protected animal used as medicine, although the practice is rare, namely the sun bear (Helarctos malayanus) by taking its liver to treat shortness of breath. Sun bear is one of the protected animals listed under Appendix I of CITES (Convention on International Trade in Endangered Species), as well as protected under Government Regulation of the Republic of Indonesia number 7 of 1999, Law number 5 of 1990 (BBKSDA Riau, 2018).

Cultural works produced by the community by utilizing the diversity of plants include: pandanus mats from pandan (Pndanus sp.) thorns and lukah / bubu from bamboo used to catch fish, although they have not been managed specifically. There is no group of pandan mat craftsmen or lukah, although the products have reached Malaysia, based on orders by one or two consumers (not produced in large quantities, only by consumer demand). The people of Temiang Village considered the economic potential of the product to be low and not potentially touristy. The most traditional rituals performed by the people of Temiang Village are Tepung Tawar that is carried out during the wedding ceremony; Beliman bath is carried out in every Islamic commemoration day, as well as Kenduri which is carried out to welcome the fasting month of Ramadhan.

Plant species that is usually used in traditional ritual activities are rice, potpourri, fragrant pandanus (Pandanus amaryllifolius), glutinous rice (Oryza glutinosa), turmeric (Curcuma longa) and lime leaves (Citrus sp). For the people of Temiang Village, there is no traditional ritual considered to have economic value and attractions. The most commonly mentioned artwork by the Temiang villagers is the Zapin dance. This Zapin dance is usually performed in large religious celebrations, to welcome large guests as well as at wedding ceremonies. In the implementation of this dance, dancers will wear traditional clothes accompanied by Malay music, kompang and tambourine instrument. Zapin dancers also carried betel leaves (Piper betle) and rice (Oryza sativa) placed on the treads (plates) used at the beginning and end of the dance.

In Sepahat Village found 36 species of plants that are often used as medicine, mostly from the Zingiberaceae family, with the highest species is turmeric plant (Curcuma domestica). Sequentially the most used parts of plants as medicine by Sepahat villagers are: leaves, rhizomes, fruits, stems, bark, leaves and roots, leaves and fruits, jellies, and buds. Explained by Aisha (2015) the high frequency of utilization of leaf parts as medicinal ingredients related to some advantages such as : the huge number, leaves are easier to obtain compared to other parts and easier to process. Medicinal plants mentioned by Sepahat villagers are used to treat various diseases such as; hemorrhoids, shortness of breath, lumbago, yellow sap, aches and sprains, flatulence, nosebleeds, diarrhea, diabetes, obesity, increase stamina and endurance, repel insects, cure external wounds, increase stamina of postpartum mothers, increase appetite, increase breast milk and dengue fever, expel colds, cholesterol, fever, hypertension, cough and whitish. Sepahat villagers do not put special efforts in preserving the species of plants that are used as medicine. This is due to the large number of plants and they could easily found in plantation areas and community yards. Meanwhile, the type of root plants hooks are getting fewer in the forest area due to the changing function of forests into plantations and also forest fire incident.

The six species of animals most commonly used as medicine are squirrels (Scandentia sp.) 25\%, snakes (Serpentes sp.) 20\%, greater coucal (Centropus sinensis) 11\%, ant-lion (Myrmeleon formicarius) 8\%, seahorses (Hippocampus sp.) $7 \%$ and thousand feet (Myriapoda sp.) $7 \%$. From the 12 species of animals used as medicine, there are four types of animals which have protected status according to Ministry of Environment and Forestry decree Number P.106 Year 2018, namely lathes, shoehorse crab, sun bears and seahorses. The practice of using these animals as medicine is still common, though the number of these animals found in forest and marine areas already decreasing due to poaching and illegal trading. The most widely used parts of the animal's body as medicine are the meat as much as $67 \%$, the bile $17 \%$, the liver $8 \%$ and the egg $8 \%$. Diseases treated by utilizing these animals include: shortness of breath or asthma, eye pain, fever, diabetes, rheumatism, thypoid, sprains and fractures, postoperative wounds, increased fertility and toothache.

The most mentioned cultural work by Sepahat villagers is traditional food and drink (56\%). Furthermore, chicken mat pandanus, woven lukah or bubu, woven dishes and baskets and woven climb each showed a value of $11 \%$. Traditional ritual activities that are still carried out include: ritual bath to resist bad luck (water war) $45 \%$, tepung tawar andkenduri $36 \%$ which carried out during the wedding ceremony. The most commonly called art activities are Zapin dance (22\%), kompang art $(19 \%)$, art in the form of stage house models and lembayung or roof hats $(16 \%)$, rhythmic reverse art or Berbalas Pantun (10\%), Silat martial art $(10 \%)$, tambourine instrument art $(10 \%)$, sekapur sirih dance $(6 \%)$ and Serampang Dua Belas dance $5 \%$.

\section{GONGLUSION}

Biodiversity in the PT SPM found 177 species of plants which 13 of them are protected, 55 species of animals of which 33 are protected status. In PT BBHA 
found 146 species of plants which 18 of them are protected, 46 species of animals of which 21 are protected. In the village of Temiang found 51 species of plants which 2 of them are protected, there are 18 species of animals of which 8 are protected. In Sepahat Village found 73 species of plants, 6 of which are protected, there are 83 species of animals and 44 of them are protected.

Traditional knowledge of medicine, cultural works and community artworks in two villages is closely related to biodiversity. Traditional medicine of Temiang villagers utilizes 11 species of plants and 10 species of animals, 3 of which are protected. Traditional medicine of Sepahat villagers utilizes 36 species of plants and 12 species of animals (3 of which are protected). The cultural work in Temiang village utilizes 7 species of plants, while in the artwork Temiang people make use of 2 species of plants. The cultural work in Sepahat Village utilizes 26 species of plants and 1 species of animals. In the artwork, Sepahat villagers make use of 8 species of plants and 2 species of animals.

\section{AGKNOWLEDGMENTS}

This research was supported by Asia Pulp and Paper Sinarmas, Balai Besar of Natural Resources Conservation (BBKSDA) of Riau Province and the Government of Bengkalis District.

\section{REFERENGES}

Afriyansyah, B. et all. 2016. Utilization of Animals as Traditional Medicine by Ethnic Lom in Bangka. Journal of Science Research. Volume 18, No.2

Atsar, A. 2017. Legal Protection of Traditional Cultural Knowledge and Expression to Improve Public Welfare Reviewed from Law No. 5 of 2017 on The Promotion of Culture and Law No.28 of 2014 on Copyright. Journal Law Reform. Volume 13 No.2

Azlan, M. 2019. Profil Desa Sepahat Kecamatan Bandar Laksamana Kabupaten Bengkalis Tahun 2019. Pemerintah Desa Sepahat. Desa Sepahat.

BKSDA Riau. 2017. Rencana Pengelolaan Jangka Panjang Suaka Margasatwa, Bukit Batu Kabupaten Bengkalis Provinsi Riau. Balai Besar Konservasi Sumber Daya Alam. Provinsi Riau

BPS. 2019. Kabupaten Bengkalis dalam Angka. Badan Pusat Statistik. Kabupaten Bengkalis.

Fandeli, C et all. 2000. Ecotourism Business, Faculty of Forestry UGM, Yogyakarta.

Ferianto. 2017. Model Pengelolaan Ekosistem Kawasan Penyangga Cagar Biosfer Giam Siak Kecil : Studi Kasus PT. Sekato Pratama Makmur. Proseding Seminar Nasional LIPI. Ecosystem Management Model of Giam Siak Small Biosphere
Reserve Buffer Zone: Case Study of PT. Sekato Pratama Makmur. Proceeding of the National Seminar, LIPI. Vol.1. Hal. 285

Handayani, A. 2015. Pemanfaatan Tumbuhan Berkhasiat Obat oleh Masyarakat Sekitar Cagar Alam Gunung Simpang Jawa Barat. Proseding Seminar Nasional Masyarakat Biodiversitas Indonesia. 2 Juli 2015. Vol.1.No.6. Hal. 1425-1432.

Hijri, Z. 2013. Pengelolaan Kebun Karet Rakyat di Area Transisi Cagar Biosfer Giam Siak Kecil Bukit Batu. Tesis S2 Ilmu Kehutanan. Universitas Gadjah Mada.

Juliarti, A. 2013. Utilization of HHBK (Non-Timber Forest Products) and Identification of Medicinal Plants in the Area of Biosphere Reserve Giam Siak Kecil Bukit Batu Siak. Journal of Tropical Forests. Volume 1, No.1

Kementerian Lingkungan Hidup dan Kehutanan Republik Indonesia. 2018. Peraturan Menteri Lingkungan Hidup dan Kehutanan Republik Indonesia Nomor P.106 / MENLHK/SETJEN/KUM.1/12/2018 Tentang Perubahan Kedua Atas Peraturan Menteri Lingkungan Hidup dan Kehutanan Nomor P.20/MENLHK/SEKJEN/KUM. 1/6/2018 Tentang Jenis Tumbuhan dan Satwa Yang Dilindungi. Berita Negara Republik Indonesia Tahun 2019 No.32. 21 Januari 2019. Jakarta.

LIPI. 2008. Laporan Akhir Kerjasama LIPI - PT. Arara Abadi : Kajian Keanekaragaman Hayati di Kawasan Giam Siak Kecil Bukit Batu. Bogor.

Man and Biosphere-Indonesia. 2008. Proposal Manajemen Plan Cagar Biosfer Giam Siak Kecil-Bukit Batu. Provinsi Riau.

Masdar. 2019. Profil Desa Temiang Kecamatan Bandar Laksamana Kabupaten Bengkalis Tahun 2019. Pemerintah Desa Temiang. Desa Temiang.

Peraturan Menteri Pariwisata Republik Indonesia No.14 Tahun 2016 Tentang Pedoman Destinasi Pariwisata Berkelanjutan. Berita Negara Republik Indonesia Tahun 2016 No.1303. 1 September 2016. Jakarta

Peraturan Menteri Lingkungan Hidup dan Kehutanan Republik Indonesia No.P.17/MENLHK/SETJEN/KUM. 1/2/2017 Tentang Perubahan Atas Peraturan Menteri Lingkungan Hidup dan Kehutanan No.P.12/MENLHK-II /2015 Tentang Pembangunan Hutan Tanaman Industri. Berita Negara Republik Indonesia Tahun 2017 No.339. 27 Februari 2017. Jakarta

Qodriyatun, S.N. 2016. Perlindungan Terhadap Pengetahuan Tradisional Masyarakat Atas Pemanfaatan Sumber Daya Genetik (SDG). Pusat Penelitian Badan Keahlian DPR-RI. Jakarta

Qomar, N. 2017. Kebijakan Pengelolaan Sumber Daya Cagar Biosfer Giam Siak Kecil-Bukit Batu. Disertasi Pasca Sarjana IPB. Bogor. 
Riduwan. 2010. Dasar-dasar Statistika. Alfabeta. Bandung

Risnandar, C. 2018. Biosphere Reserve. http://www.jurnalbumi.com/knol/cagar-biosfer/

Sirait, I,G. 2015. Government Responsibility for Biosphere Reserve Giam Siak Kecil Bukit Batu Based on International Environmental Law. Journal of Magister Faculty of Law, Volume 2. No.2

Sugiyono. 2010. Research Method of Quantitative, Qualitative and R\&D. Alfabeta. Bandung.
Undang-Undang No.5 Tahun 1994 Tentang Pengesahan United Nation Convention on Biological Diversity (Konvensi Perserikatan Bangsa-Bangsa Mengenai Keanekaragaman Hayati). Lembaran Negara Republik Indonesia Tahun 1994 No.41. 1 Agustus 1994. Jakarta.

UNESCO. 2020. Biosphere Reserves Learning Sites for Sustainable Development.

http://www.unesco.org/new/en/natural-sciences/environme nt/ecological- sciences/biosphere-reserves/ 